\title{
Genotyping of Chlamydia trachomatis from clinical specimens in Taiwan
}

\author{
Min-Chih Hsu, ${ }^{1}$ Pei-Yi Tsai, ${ }^{1}$ Kow-Tong Chen, ${ }^{2}$ Lan-Hui Li, ${ }^{3}$ \\ Chien-Chou Chiang, ${ }^{3}$ Jih-Jin Tsai, ${ }^{4}$ Liang-Yin Ke, ${ }^{4}$ Hour-Young Chen ${ }^{1}$ \\ and Shu-Ying $\mathrm{Li}^{1}$ \\ ${ }^{1}$ Laboratory for Bacteriology and Mycology, Center for Laboratory Research and Diagnostics, \\ Center for Disease Control, Taipei, Taiwan \\ ${ }^{2}$ Department of Public Health, College of Medicine, National Cheng Kung University, Tainan, \\ Taiwan \\ ${ }^{3}$ Taipei City Hospital, Branch for Disease Control \& Prevention, Taipei, Taiwan \\ ${ }^{4}$ Chung-Ho Memorial Hospital, Kaohsiung Medical University, Kaohsiung, Taiwan
}

Correspondence

Shu-Ying Li

syl@cdc.gov.tw

Received 26 July 2005

Accepted 15 November 2005

\begin{abstract}
This study was conducted to determine the prevalence and distribution of Chlamydia trachomatis genotypes in Taiwan. Urine and endocervical-swab samples were collected from two hospitals located in northern and southern Taiwan. The genotypes of a total of 145 samples positive for C. trachomatis were analysed by sequencing the omp1 gene and this was successful in 102 samples. Nine different C. trachomatis genotypes were identified. Genotype E was the most prevalent (22\%), followed by D and Da (19\%), F (16\%), J (15\%), K (11\%), G (11\%), H (6\%) and $\mathrm{Ba}(2 \%)$. There was a geographical difference in the prevalence of genotype $\mathrm{H}(P<0.018)$ between northern and southern Taiwan. Sequence mutation analysis by BLAST searching against GenBank reference sequences identified 12 genetic variants from a total of $102 \mathrm{omp} 1$ gene sequences.
\end{abstract}

\section{INTRODUCTION}

Chlamydia trachomatis infection is the most prevalent sexually transmitted bacterial disease. It is estimated that 89 million cases occur annually worldwide (Gaydos et al., 2004). Because in $50 \%$ of men and $80 \%$ of women infected individuals are asymptomatic, the actual number of reported cases represents only a fraction of the infected population (Gaydos et al., 2004). Currently 19 human serovars and related variants (A, B/Ba, C, D/Da, E, F, G, Ga, H, I/Ia, J, K, L1, L2, L2a and L3) have been identified by using polyclonal and monoclonal antibodies against the major outer-membrane protein (MOMP) (Grayston \& Wang, 1975; Ngandjio et al., 2004; Pedersen et al., 2000; Suchland \& Stamm, 1991; Wang et al., 1985; Yuan et al., 1989). Based on the pathogenic potential, serovars A, B, Ba and C are commonly associated with trachoma. Serovars $\mathrm{D}$ to $\mathrm{K}$ are commonly associated with urogenital infections, such as urethritis, epididymitis, cervicitis, salpingitis, pelvic inflammatory disease and ectopic pregnancy; serovars L1 to L3 are commonly associated with lymphogranuloma venereum (Yuan et al., 1989).

\footnotetext{
Abbreviation: STD, sexually transmitted disease.
}

The GenBank/EMBL/DDBJ accession numbers for the partial omp 1 sequences from $C$. trachomatis strains determined in this work are DQ155295-DQ155300 and DQ287919-DQ287921.
Furthermore, suggestions have been made that the infections with $C$. trachomatis serovars $\mathrm{G}, \mathrm{I}$ and $\mathrm{D}$ are associated with cervical squamous cell carcinoma, and chronic infections with serotype $\mathrm{K}$ in women have been recognized as a cause of infertility (Anttila et al., 2001; Koskela et al., 2000; Marrazzo \& Stamm, 1998; Morre et al., 2000).

Serological typing methods have a limitation in that newly emerging types may be missed and culturing of clinical isolate is usually required (Eckert et al., 2000; Suchland \& Stamm, 1991). Compared to serotyping, the genotyping methods are more sensitive and specific for $C$. trachomatis serovar identification (Molano et al., 2004). Many studies have shown the feasibility of deducing the serotypes of C. trachomatis clinical isolates using PCR-based RFLP or sequencing of the amplified ompl gene that encodes the MOMP, the main surface antigen of $C$. trachomatis (Ikehata et al., 2000; Lysén et al., 2004; Ngandjio et al., 2003, 2004; Singh et al., 2003). The omp1 gene exhibits extensive DNA sequence variation in four discrete regions, termed variable segments (VS1-4) (Stephens et al., 1987; Yuan et al., 1989). Sequence analysis of the variable segments of the C. trachomatis omp1 genes revealed immunogenic epitopes, which is beneficial for vaccine studies (Peterson et al., 1999; Stothard et al., 1998). Furthermore, by sequencing these four variable segments, subtle sequence differences within the same $C$. 
trachomatis genotype can be identified, which provides a valuable and sensitive means for molecular epidemiological analysis to identify high risk groups and track sexual networks (Cabral et al., 2003; Lee et al., 2006). For example, a new genovariant of $C$. trachomatis, L2b, was primarily responsible for outbreaks of lymphogranuloma venereum among high-risk core groups (HIV positive men who have sex with men) in the Netherlands (Spaargaren et al., 2005).

In Taiwan, although the incidence and prevalence of $C$. trachomatis genital infection is rising, only limited information is available (Hsieh et al., 1999; Wu et al., 1992). The aims of the present study were to conduct sequence analysis of the ompl gene to determine the genotypes and variants of C. trachomatis strains causing genital infections in Taiwan. Such data may give insights into the epidemiology of $C$. trachomatis strains circulating in Taiwan, and contribute to improved control measures in the future.

\section{METHODS}

Clinical samples. The study was part of a sexually transmitted disease (STD) surveillance project approved by an STD review committee from the Center for Disease Control, Taiwan, and informed consent was obtained from patients before sample collection. During the period December 2003 to October 2005, 1253 urine and 1151 endocervical-swab samples were collected for detection of C. trachomatis from 2360 patients visiting two hospitals for genital chlamydia infection examination. The two hospitals are located in Taipei and Kaohsiung, which are the two largest metropolitan cities located in northern and southern Taiwan, respectively. Among these samples, 476 endocervical-swab samples and 1253 urine samples were from Taipei, and 675 endocervical-swab samples were from Kaohsiung. There were 44 patients with both urine and endocervical-swab specimens in Taipei. Specimens were collected according to the manufacturer's instructions for the COBAS AMPLICOR C. trachomatis test (Roche Diagnostic Systems). The criteria used for determining positive and negative samples depended on the absorbance at a wavelength of $660 \mathrm{~nm}$. In this test, negative and positive controls should be included in each run. The absorbance of the negative control should be less than $0 \cdot 2$ and of the positive control should be greater than $2 \cdot 0$ at $660 \mathrm{~nm}$. If the absorbance of the negative control is greater or equal to 0.2 and positive control is less than 2.0 at $660 \mathrm{~nm}$, the entire run is invalid. Properly processed specimens should give positive results with an absorbance greater than or equal to 0.8 at $660 \mathrm{~nm}$. The negative result is below $0 \cdot 2$. Between the absorbance of $0 \cdot 2$ and $0 \cdot 8$, the test should be repeated in duplicate on processed specimen. C. trachomatis-positive samples (original urine and endocervical-swabs) were frozen at $-70^{\circ} \mathrm{C}$ for further analysis.

DNA extraction. DNA was extracted using the QIAamp viral RNA minikit (Qiagen) for urine and endocervical-swabs samples according to the manufacturer's instructions (Lysén et al., 2004). These samples were concentrated by centrifugation for $5 \mathrm{~min}$ at $13000 \mathrm{~g}$ prior to DNA extraction. The DNA was frozen at $-20^{\circ} \mathrm{C}$ for nested PCR.

PCR. Primary amplification of an approximately 1130 bp fragment encompassing VS1-4 of omp1 was performed using the outer primer pair NLO/NRO (Ngandjio et al., 2004), and reamplification of a 584 bp fragment spanning VS1-2 was conducted based on the inner primer pair MOMP87/C214 (Table 1) (Stothard et al., 1998). The first PCR step was carried out in a final reaction volume of $25 \mu \mathrm{l}$, containing $0 \cdot 4 \mu \mathrm{M}$ each NLO/NRO outer primer pair, $5 \mu \mathrm{l}(50 \mathrm{ng})$ extracted DNA and $12.5 \mu \mathrm{l} 2 \times$ PCR master mix (MBI Fermentas). The amplification conditions consisted of initial polymerase activation at $95^{\circ} \mathrm{C}$ for $5 \mathrm{~min} ; 35$ cycles of $94^{\circ} \mathrm{C}$ for $60 \mathrm{~s}, 54{ }^{\circ} \mathrm{C}$ for $60 \mathrm{~s}$ and $72{ }^{\circ} \mathrm{C}$ for $80 \mathrm{~s}$; and a final elongation step at $72^{\circ} \mathrm{C}$ for $10 \mathrm{~min}$. A negative water control was included in each run. In the second PCR step, $3 \mu \mathrm{l}$ product from the first PCR step and $0 \cdot 4 \mu \mathrm{M}$ each MOMP87/C214 inner primer pair was added to a final volume of $25 \mu$ l. The PCR conditions were: $95^{\circ} \mathrm{C}$ for $5 \mathrm{~min}$; 35 cycles of $94{ }^{\circ} \mathrm{C}$ for $50 \mathrm{~s}, 56^{\circ} \mathrm{C}$ for $50 \mathrm{~s}$ and $72^{\circ} \mathrm{C}$ for $50 \mathrm{~s}$; and a final elongation step at $72^{\circ} \mathrm{C}$ for $10 \mathrm{~min}$. The amplified products were electrophoresed through a $2 \%$ agarose gel and visualized by staining with ethidium bromide.

DNA sequencing. A total of 102 ompl fragments successfully amplified from the 145 C. trachomatis-positive samples were purified using a QIAquick PCR purification kit (Qiagen), and strands of $584 \mathrm{bp}$ and $1130 \mathrm{bp}$ fragments of the omp1 segment were sequenced using a BigDye terminator cycle sequencing ready reaction kit (Applied Biosystems). The reaction mixtures were loaded onto a 3730 Avant genetic analyser (Applied Biosystems). The primer sets used for sequencing were MOMP87/C214 and NLO/NRO. All the PCR products were sequenced bidirectionally.

BLAST analysis and alignments. The consensus sequences were compared to sequences of known $C$. trachomatis strains by BLAST searching GenBank (www.ncbi.nlm.nih.gov/GenBank). The sequences were assembled into alignments using reference sequences derived from GenBank: B/IU-1226 (AF063208), B/B-16 (AY950630), D/B-120 (X62918), Da/TW-448 (X62921), E/Bour (X52557), F/ICCal3 (X52080), G/UW57 (AF063199), H/Wash (H/UW4) (X16007), J/UW36 (AF063202) and K/UW31 (AF063204). Multiple alignments were performed with BioEdit version 7.0 software. The sequence data of new variants were submitted to NCBI and have the following accession numbers: E3 (DQ155295), E5 (DQ155296), E4 (DQ155297), E2 (DQ155298), G2 (DQ155299), K2 (DQ155300), G3 (DQ287919), H2 (DQ287920) and J2 (DQ287921).

Statistical analysis. We used the chi-square tests of the SPSS version 10.0 software to establish relationships between genotypes and clinical features (specimen type, HIV status, age or sex) as well as geographical parameters.

Table 1. Primers used for the nested PCR of the omp1 gene

\begin{tabular}{|lllc|}
\hline Primer & Strand & \multicolumn{1}{c|}{ Sequence $\left(\mathbf{5}^{\prime} \mathbf{3}^{\prime}\right)$} & Position \\
\hline NLO & Sense & ATGAAAAAACTCTTGAAATCG & $1-21$ \\
NRO & Antisense & CTCAACTGTAACTGCGTATTT & $1108-1128$ \\
MOMP87 & Sense & TGAACCAAGCCTTATGATCGACGGA & $87-111$ \\
C214 & Antisense & TCTTCGAYTTTAGGTTTAGATTGA & $648-671$ \\
\hline
\end{tabular}




\section{RESULTS}

\section{C. trachomatis prevalence}

Of the total 2404 samples, 145 samples (6\%) were positive for $C$. trachomatis in a routine Roche COBAS AMPLICOR PCR test; 79 out of $1253(6 \%)$ urine samples and 39 out of 476 (8\%) endocervical-swab samples from Taipei, and 27 out of 675 (4\%) endocervical-swab samples from Kaohsiung were $C$. trachomatis positive.

\section{Genotyping}

Sequence analysis of the $584 \mathrm{bp}$ and $1130 \mathrm{bp}$ fragments of the omp1 gene, comprising VS1-2 and VS1-4, was achieved from nested PCR amplified DNA in $102(70 \%)$ of the total 145 C. trachomatis-positive samples. Genotype E was the most prevalent (22\%), followed by D and Da (19\%), F (16\%), J (15\%), G (11\%), K (11\%), H (6\%) and Ba (2\%) (Table 2). Genotype $\mathrm{Ba}, \mathrm{D}, \mathrm{Da}$ and $\mathrm{F}$ showed no variation, and were identical to the reference strains used. Of the 102 samples, we observed 12 different omp1 nucleotide sequences. Multiple sequence alignment of the sequences from all 102 samples showed a total of 17 different variable nucleotide positions, of which 13 resulted in amino acid replacements. All of the mutation positions were rechecked by repeating the nested PCR and then sequencing the fragments bidirectionally.

For genotype E, 4 out of 22 samples ( $18 \%$ ) differed from the reference strains E/Bour. The nucleotide substitutions at positions $258,321,572$ and 637 , changing base pair $\mathrm{C}$ to $\mathrm{A}, \mathrm{T}$ to $\mathrm{C}, \mathrm{T}$ to $\mathrm{C}$ and $\mathrm{T}$ to $\mathrm{C}$, respectively, caused the amino acid to change from Asp to Glu, Pro to Pro (silent), Phe to Ser and Phe to Leu, respectively (see Table 3 ). For genotype G, 2 out of 11 samples $(18 \%)$ differed from the reference strain G/UW57. The G2 sample had three nucleotide substitutions at positions 88,89 and 91 that showed $\mathrm{T}$ to $\mathrm{C}, \mathrm{A}$ to $\mathrm{G}$ and $\mathrm{G}$ to $\mathrm{T}$ variations, respectively, and caused the amino acid to change from Arg to Arg (silent), Met to Val and Met to Val, respectively. The G3 sample had only one mutation at

Table 2. Distribution of 584 and 1130 bp sequence fragments in different serovars of $C$. trachomatis

\begin{tabular}{|lccc|}
\hline Genotype & $\begin{array}{c}\text { No. of } \\
\text { cases (\%) }\end{array}$ & \multicolumn{2}{c|}{ No. of cases (\%) with: } \\
\cline { 3 - 4 } & & $\mathbf{5 8 4}$ bp fragment & $\mathbf{1 1 3 0}$ bp fragment \\
\hline B & $2(2)$ & $1(50)$ & $1(50)$ \\
D & $19(19)$ & $11(58)$ & $8(42)$ \\
E & $22(22)$ & $14(64)$ & $8(36)$ \\
F & $16(16)$ & $11(69)$ & $5(31)$ \\
G & $11(11)$ & $9(82)$ & $2(18)$ \\
H & $6(6)$ & $4(67)$ & $2(33)$ \\
J & $15(15)$ & $9(60)$ & $6(40)$ \\
K & $11(11)$ & $6(55)$ & $5(45)$ \\
Total & 102 & $65(64)$ & $37(36)$ \\
\hline
\end{tabular}

position 392, which showed a $G$ to A variation, and changed the amino acid from Gly to Ser. For genotype K, compared to K/UW31, two samples $(2 / 11,18 \%)$ both had two nucleotide substitutions at positions 283 and 293 , leading to $G$ to $\mathrm{A}$, and A to G variations, respectively, and causing Gly and Asn, respectively, both to be replaced by Ser.

A high mutation rate $(4 / 6,67 \%)$ was found for genotype $\mathrm{H}$ compared with the reference strain H/Wash (H/UW4). Nucleotide substitutions at positions $440,675,682,778$ and 1018 were identified in our genotype $H$, leading to $A$ to $G, T$ to $\mathrm{A}, \mathrm{A}$ to $\mathrm{G}, \mathrm{C}$ to $\mathrm{T}$ and $\mathrm{C}$ to $\mathrm{T}$ mutations, respectively, and causing the amino acid to change from Asn to Ser, Asp to Glu, Thr to Ala, Leu to Phe and Leu to Leu (silent), respectively. In our 15 confirmed genotype J samples, all of them $(15 / 15,100 \%)$ differed from reference strain J/UW36 at the 369 position. One sample, J2, had another mutation at position 572. After BLAST searching, we found that the position 369 mutation was the same as the sequence of the $C$. trachomatis J/isolate 6858 (AY950622) from China, not the reference strain J/UW36.

\section{DISCUSSION}

To our knowledge, this is the first paper on genotype distribution of C. trachomatis genital infections in Taiwan. In this study, we found that genotype $\mathrm{E}$ was the most common genotype (22\%), followed by genotypes D (19\%), F (16\%), $\mathrm{J}(15 \%), \mathrm{G}(11 \%), \mathrm{K}(11 \%), \mathrm{H}(6 \%)$ and genotype B (2\%). Genotype B was rarely involved in urogenital infections in Taiwan, which is in accordance with previous findings. Table 4 shows the distribution of $C$. trachomatis genotypes in Asian countries. In Asia, there is little data on the distribution of the C. trachomatis genotypes. From our result, $\mathrm{E}, \mathrm{D}$ and $\mathrm{F}$ were the top three genotypes in Taiwan, similar results were found in Japan and Korea. In Thailand, F (25-60\%) was the most prevalent genotype followed by E (9-20\%) and D (7-23\%) (Table 4). Differences in genotype prevalence were found in different study populations. In Thailand, for example, in non-sex workers, $\mathrm{F}(60 \%)$ was the most predominant genotype, while in sex workers the rate of F genotype decreased to $29 \%$ (Yamazaki et al., 2005).

Other studies have reported the genetic variability of the omp1 gene sequences as ranging from $10 \%$ to $81 \%$ (Brunham et al., 1996; Dean et al., 1995; Frost et al., 1995; SturmRamirez et al., 2000). We found 12 genetic variants out of a total of 102 omp1 gene sequences. No variant was identified for genotypes $\mathrm{Ba}, \mathrm{D}, \mathrm{Da}$ and $\mathrm{F}$ compared to the reference strains. For the most prevalent genotype E, four samples were diverged $(4 / 22,18 \%)$ from the reference sequence E/Bour, which was analogous to a prior study reporting on the genetic variants of $\mathrm{E}$ strains $(11 / 67,16 \%)$ (Dean \& Millman, 1997). For genotype G, two new variants $(2 / 11$, $18 \%$ ) were identified with nucleotide mutations at one and three positions, respectively. For genotype K, two new variants $(2 / 11,18 \%)$ were discovered, each with two nucleotide mutations. The mutation positions in the genotype $\mathrm{E}, \mathrm{G}$ and 
Table 3. Nucleotide changes found in the 12 genetic variants out of the 102 clinical C. trachomatis specimens compared to reference sequences

The following reference strains were used for comparison with the sequences obtained in this study: B/B-16, identical to Ba; D/B-120, identical to D1; Da/TW-448, identical to D2; E/Bour, identical to E1; F/IC-Cal3, identical to F; G/UW57, identical to G1; H/Wash (H/UW4), identical to H1; J/UW36, identical to $\mathrm{J} 1$; K/UW31, identical to $\mathrm{K} 1$.

\begin{tabular}{|c|c|c|c|c|}
\hline $\begin{array}{l}\text { Genotype } \\
\text { (no. of cases) }\end{array}$ & $\begin{array}{c}\text { No. of strains } \\
\text { with nucleotide } \\
\text { changes/total (\% } \\
\text { with changes) }\end{array}$ & $\begin{array}{l}\text { Nucleotide } \\
\text { change }\end{array}$ & Position* & $\begin{array}{l}\text { Amino acid } \\
\text { change }\end{array}$ \\
\hline $\mathrm{Ba}(2)$ & No variant & & & \\
\hline D1 (13) & No variant & & & \\
\hline Da2 (6) & No variant & & & \\
\hline \multicolumn{5}{|l|}{ E1 (18) } \\
\hline E2 (1) & $1 / 22(5)$ & $\mathrm{C}$ to $\mathrm{A}$ & 258 & Asp to Glu \\
\hline E3 (1) & $1 / 22(5)$ & $\mathrm{T}$ to $\mathrm{C}$ & 321 & Silent \\
\hline E4 (1) & $1 / 22(5)$ & $\mathrm{T}$ to $\mathrm{C}$ & 572 & Phe to Ser \\
\hline E5 (1) & $1 / 22(5)$ & $\mathrm{T}$ to $\mathrm{C}$ & 637 & Phe to Leu \\
\hline F (16) & No variant & & & \\
\hline \multicolumn{5}{|l|}{ G1 (9) } \\
\hline \multirow[t]{3}{*}{ G2 (1) } & 1/11 (9) & $\mathrm{T}$ to $\mathrm{C}$ & 88 & Silent \\
\hline & $1 / 11(9)$ & A to $\mathrm{G}$ & 89 & Met to Val \\
\hline & 1/11 (9) & $\mathrm{G}$ to $\mathrm{T}$ & 91 & Met to $\mathrm{Val}$ \\
\hline G3 (1) & 1/11 (9) & $\mathrm{G}$ to $\mathrm{A}$ & 392 & Gly to Ser \\
\hline \multicolumn{5}{|l|}{ H1 (2) } \\
\hline \multirow[t]{2}{*}{$\mathrm{H} 2(1)$} & $4 / 6(67)$ & A to $\mathrm{G}$ & 440 & Asn to Ser \\
\hline & $1 / 6(17)$ & $\mathrm{C}$ to $\mathrm{T}$ & 778 & Leu to Phe \\
\hline \multirow[t]{2}{*}{ H3 (2) } & $4 / 6(67)$ & A to $G$ & 440 & Asn to Ser \\
\hline & $2 / 6(33)$ & $\mathrm{C}$ to $\mathrm{T}$ & 1018 & Silent \\
\hline \multirow[t]{3}{*}{ H4 (1) } & $4 / 6(67)$ & A to $G$ & 440 & Asn to Ser \\
\hline & $1 / 6(17)$ & $\mathrm{T}$ to $\mathrm{A}$ & 675 & Asp to Glu \\
\hline & 1/6 (17) & A to $\mathrm{G}$ & 682 & Thr to Ala \\
\hline J1 (14) & $15 / 15(100)$ & $\mathrm{C}$ to $\mathrm{T}$ & 369 & Silent \\
\hline \multirow[t]{2}{*}{$\mathrm{J} 2(1)$} & $15 / 15(100)$ & $\mathrm{C}$ to $\mathrm{T}$ & 369 & Silent \\
\hline & $1 / 15(7)$ & A to $\mathrm{G}$ & 572 & Asp to Gly \\
\hline \multicolumn{5}{|l|}{ K1 (9) } \\
\hline \multirow[t]{2}{*}{ K2 (2) } & 2/11 (18) & $\mathrm{G}$ to $\mathrm{A}$ & 283 & Gly to Ser \\
\hline & 2/11 (18) & A to $G$ & 293 & Asn to Ser \\
\hline
\end{tabular}

${ }^{*}$ Position refers to the reference sequence of each serotype and is not homologous between serotypes.

$\mathrm{K}$ samples in this study were all new compared with other papers reporting the analysis of mutation sites (Cabral et al., 2003; Jurstrand et al., 2001; Lister et al., 2004b; Lysén et al., 2004; Ngandjio et al., 2003; Pedersen et al., 2000). Four genetic variants $(67 \%)$ were identified in our genotype $\mathrm{H}$ samples. After BLAST searching at the NCBI, we found the mutations at positions 440 and 1018 of $\mathrm{H} 3$ were identical to the C. trachomatis isolate H/IS 1075 (AF414959) from Iceland, not the reference strain H/Wash (H/UW4). In Sweden, Lysén et al. (2004) have reported the same mutation at positions 440 and 1018 of genotype $\mathrm{H}$. The mutation at position 778 in $\mathrm{H} 2$ was a new finding. The mutations at positions 440, 675 and 682 of $\mathrm{H} 4$ were the same as those reported by Lysén et al. (2004).
For genotype J, fifteen sequences of genotype J were confirmed to be identical to the C. trachomatis J/isolate 6858 (AY950622) isolated from China in 2005, not the generally used reference strain J/UW36. The J2 genotype sample was found to have one additional mutation at position 572 . Compared with the Ja genotype reported from the United States and Jv genotypes reported from the Netherlands (Dean et al., 2000; Morre et al., 1998), our genotype J was quite different. Our J1 and J2 genotypes exhibited only two mutations at position 369 and 572, and both were new compared to the reported Ja and Jv genotypes. The two mutation sites were in the conserved segment 2 and 3 . Compared with the reference strain J/UW36, mutation at residue 369 of our genotype J changed $\mathrm{C}$ to $\mathrm{T}$, and resulted 
Table 4. Distribution of genotypes of C. trachomatis in Asia in recent years

\begin{tabular}{|c|c|c|c|c|}
\hline $\begin{array}{l}\text { Typing } \\
\text { method }\end{array}$ & $\begin{array}{l}\text { Sample no. } \\
\text { for typing }\end{array}$ & Genotype distribution & Country & Reference \\
\hline RFLP & 207 & E (24\%), D (19\%), G (18\%), F (11\%), H (7\%), I (7\%), K (4\%) & Japan & Ikehata et al. (2000) \\
\hline $\begin{array}{l}\text { RFLP, dot- } \\
\text { ELISA }\end{array}$ & 28 & $\mathrm{E}>\mathrm{D}>\mathrm{F}>\mathrm{H}$ & Korea & Choi et al. (2001) \\
\hline Sequencing & 45 & $\begin{array}{l}\text { F }(25 \%), D(23 \%), H(12 \%), K(12 \%), \text { E }(9 \%), \text { Ia }(7 \%), \text { B }(7 \%) \\
\text { Ja }(5 \%), \text { G }(2 \%)\end{array}$ & Thailand & Bandea et al. (2001) \\
\hline RFLP & 56 & $\begin{array}{l}\text { F }(29 \%), \mathrm{E}(20 \%), \mathrm{K}(18 \%), \mathrm{D}(14 \%), \mathrm{G}(7 \%), \mathrm{H}(5 \%), \mathrm{J}(5 \%) \\
\text { I }(2 \%), \mathrm{Ba}(2 \%)\end{array}$ & Thailand & Yamazaki et al. (2005) \\
\hline
\end{tabular}

in a silent substitution, which has been described by others (Jurstrand et al., 2001; Ngandjio et al., 2003). Interestingly, there was significantly higher mutation rate at position 369 of genotype J in Taiwan (15/15, $100 \%)$ compared to that in Sweden (4/10, $40 \%, p<0.001)$ (Jurstrand et al., 2001) and in Cameroon $(1 / 3,33 \%, P<0.02)$ (Ngandjio et al., 2003), as analysed by Fisher's exact test.

For genotype $\mathrm{K}$, there were two variants (K2), both with the same mutation at positions 283 and 293. After BLAST searching, we found that the sequence of K2 was more similar to the C. trachomatis K/isolate 4011 (AY950621) from China than to the reference strain K/UW31. The mutation at position $283 \mathrm{~A}$ of $\mathrm{K} 2$ was new for both $\mathrm{K} /$ isolate 4011 (AY950621), and the reference strain K/UW31 (283:G). The mutation at position $293 \mathrm{G}$ of $\mathrm{K} 2$ was identical to $\mathrm{K} /$ isolate 4011 (AY950621) but different from that of the reference strain K/UW31 (293:A). A study by Parish et al. (2003) reported that the incidence of STDs is increasing rapidly in China. We found the mutants of genotype J and K identified in our research related to specific $C$. trachomatis isolates, J/isolate 6858 (AY950622) and K/isolate 4011 (AY950621) reported from China. Based on the geographical proximity of Taiwan and China, and frequent travel between the two nations such molecular data could have implications for the surveillance of $C$. trachomatis transmission.

Out of 145 C. trachomatis-positive tests from the COBAS routine analysis, the DNA of 43/145 (30\%) did not amplify using the omp1 nested PCR. This was high compared to the failure rate of 1 to $24 \%$ in similar studies (Jonsdottir et al., 2003; Jurstrand et al., 2001; Sturm-Ramirez et al., 2000). The high failure rate may be due to a lower sensitivity of the omp1 nested PCR because only a single-copy of the gene target, omp1, is present. In contrast, the COBAS AMPLICOR assay exhibited a higher sensitivity for targeting cryptic plasmid that is present as approximately 10 copies (Lister et al., 2004a; Mahony et al., 1993). Other studies also reported that positive genital samples identified using the
COBAS or ligase chain reaction (LCR) assay could not be amplified by omp1 PCR (Pedersen et al., 2000; Vincelette et al., $1999)$. Further analysis showed that DNA in 47 out of 79 $(60 \%)$ urine samples and 55 out of 66 (83\%) endocervicalswab samples could be amplified by the omp1 nested PCR, indicating a superior sensitivity of endocervical-swab specimens compared to urine specimens. A possible explanation is that urine might dilute the exfoliated urethral epithelial cells infected by C. trachomatis and cause the high failure rate of urine samples amplified by omp1 PCR. Furthermore, most women with chlamydia are infected at the cervix, a site remote from the female urethra. Hence, female urine testing may not adequately detect cervical infections (Wiesenfeld et al., 1996). A study of human papillomavirus reported that $\beta$-globin DNA was amplifiable from $87 \%$ of the cervicalswab specimens and $73 \%$ of the urine specimens $(P=0 \cdot 01)$ (Brinkman et al., 2002). Other studies reported that phosphate in urine is a powerful inhibitor of the LCR reaction, and DNA degradation is enhanced in DNase-rich body fluids like urine (Schachter et al., 2003; Woegerbauer et al., 2002). All these findings mentioned above could explain why the sequencing rate was lower in urine specimens than in endocervical-swab specimens.

In our study, all of our sequences were unambiguous and we did not find any mixed infections in one single urine or endocervical-swab specimen. There were six C. trachomatispositive patients with dual urine and endocervical-swab specimens. Among these patients, two showed dual infections of different genotypes in two kinds of specimens (urine/endocervical swab; K/G and $\mathrm{E} / \mathrm{H}$ ). The remaining four patients had identical genotypes in both specimens. Mixed infections have been reported in a single endocervical specimen, confirmed by RFLP (Ikehata et al., 2000) and different genotypes have also been found in urine and endocervical-swab specimens, respectively (Jurstrand et al., 2001). The dual infections by different genotypes in the same patient may be the result of different infection episodes, an immunity difference in different body sites or the lack of 
Table 5. Distribution of genotypes and mutations in samples from Taipei and Kaohsiung hospitals

\begin{tabular}{|c|c|c|c|c|c|}
\hline \multirow[t]{2}{*}{ Genotype } & \multicolumn{2}{|c|}{ Taipei } & \multicolumn{2}{|c|}{ Kaohsiung } & \multirow{2}{*}{$\begin{array}{l}\text { Total no. of } \\
\text { samples }(\%)\end{array}$} \\
\hline & $\begin{array}{c}\text { No. of } \\
\text { samples }(\%)\end{array}$ & $\begin{array}{c}\text { No. of } \\
\text { mutations }(\%)\end{array}$ & $\begin{array}{c}\text { No. of } \\
\text { samples }(\%)\end{array}$ & $\begin{array}{c}\text { No. of } \\
\text { mutations (\%) }\end{array}$ & \\
\hline B & $0(0)$ & 0 & $2(11)$ & 0 & $2(2)$ \\
\hline $\mathrm{D}$ & $18(22)$ & 0 & $1(5)$ & 0 & 19 (19) \\
\hline E & $20(24)$ & $4 / 20(20)$ & $2(11)$ & 0 & $22(22)$ \\
\hline $\mathrm{F}$ & $13(17)$ & 0 & $3(15)$ & 0 & $16(16)$ \\
\hline G & $9(11)$ & $2 / 9$ (22) & $2(11)$ & 0 & $11(11)$ \\
\hline $\mathrm{H}$ & $2(2)$ & $2 / 2(100)$ & $4(21)$ & $2 / 4(50)$ & $6(6)$ \\
\hline $\mathrm{J}$ & $10(12)$ & $1 / 10(10)$ & $5(26)$ & 0 & $15(15)$ \\
\hline K & $11(13)$ & $2 / 11$ & 0 & 0 & $11(11)$ \\
\hline Total & 83 & $11 / 82(13)$ & 19 & $2 / 19(11)$ & 102 \\
\hline
\end{tabular}

cross-protection between genotypes. No multiple peaks were found and the data were rechecked twice. Although the possibility could not be ruled out that differences in the nucleotide sequences (mainly primer preference), as well as in molar ratio of the individual genotypes, may lead to the different PCR performances (Bandea et al., 2001), and some genotypes may be easier to amplify using PCR than others. This may perhaps cause mixed infections to be overlooked and also lead to genotype prevalence bias (Eley \& Khalili, 1993; Pedersen et al., 2000).

In this study, no correlation between specimen type, HIV status, age or sex and genotype was found (data not shown). After further analysis, we found different genotype distributions in Taipei and Kaohsiung. Types E (24\%) and D (23\%) were predominant in Taipei. However, types J (26\%) and $\mathrm{H}$ $(21 \%)$ were more prevalent in Kaohsiung (Table 5). The percentage of genotype $\mathrm{H}$ in the two geographical regions showed significant differences $(P<0 \cdot 018)$, and no genotype $\mathrm{K}$ was found in Kaohsiung. More specimens should be gathered, especially from Kaohsiung, to further confirm such differences. The mutation rate of genotype $\mathrm{H}(4 / 6,67 \%)$ was the highest amongst the eight genotypes (Table 5), especially in Taipei where the two $\mathrm{H}$ samples were both mutant $(2 / 2,100 \%)$ compared with Kaohsiung where the rate was lower $(2 / 4,50 \%)$. For genotypes J, K, E and G, the percentage of mutants was from 10 to $22 \%$.

In conclusion, we conducted what is believed to be the first investigation into the prevalence and distribution of genotypes of C. trachomatis in Taiwan. Seven of the eight genotypes usually associated with urogenital infections were identified in our samples. Genotypes E, D and F dominated in our Taiwanese clinical material. Sequencing the omp1 gene enables analysis of sequence variations within each genotype and provides discrimination between C. trachomatis strains, which is helpful in tracing the sexual transmission pathway, which ranges from individual contact to international transportation. The data obtained in this study could have implications for the control and vaccine development of $C$. trachomatis in Taiwan.

\section{ACKNOWLEDGEMENTS}

This work was supported in part by grant DOH94-DC-2011 from the Center for Disease Control, Department of Health, Taiwan, and a pathogenic genomic databases project grant (93-0324-19-F-00-00-0035) from the National Science Council, Executive Yuan, Taiwan.

\section{REFERENCES}

Anttila, T., Saikku, P., Koskela, P. \& 12 other authors (2001). Serotypes of Chlamydia trachomatis and risk for development of cervical squamous cell carcinoma. JAMA 285, 47-51.

Bandea, C. I., Kubota, K., Brown, T. M., Kilmarx, P. H., Bhullar, V., Yanpaisarn, S., Chaisilwattana, P., Siriwasin, W. \& Black, C. M. (2001). Typing of Chlamydia trachomatis strains from urine samples by amplification and sequencing the major outer membrane protein gene (omp1). Sex Transm Infect 77, 419-422.

Brinkman, J. A., Jones, W. E., Gaffga, A. M., Sanders, J. A., Chaturvedi, A. K., Slavinsky, I. J., Clayton, J. L., Dumestre, J. \& Hagensee, M. E. (2002). Detection of human papillomavirus DNA in urine specimens from human immunodeficiency virus-positive women. J Clin Microbiol 40, 3155-3161.

Brunham, R. C., Kimani, J., Bwayo, J. \& 8 other authors (1996). The epidemiology of Chlamydia trachomatis within a sexually transmitted diseases core group. J Infect Dis 173, 950-956.

Cabral, T., Jolly, A. M. \& Wylie, J. L. (2003). Chlamydia trachomatis ompl genotypic diversity and concordance with sexual network data. J Infect Dis 187, 279-286.

Choi, T. Y., Kim, D. A. \& Seo, Y. H. (2001). Evaluation of serotyping using monoclonal antibodies and PCR-RFLP for Chlamydia trachomatis serotype identification. J Korean Med Sci 16, 15-19.

Dean, D. \& Millman, K. (1997). Molecular and mutation trends analyses of omp1 alleles for serovar E of Chlamydia trachomatis. Implications for the immunopathogenesis of disease. J Clin Invest 99, 475-483.

Dean, D., Oudens, E., Bolan, G., Padian, N. \& Schachter, J. (1995). Major outer membrane protein variants of Chlamydia trachomatis are associated with severe upper genital tract infections and histopathology in San Francisco. J Infect Dis 172, 1013-1022.

Dean, D., Suchland, R. J. \& Stamm, W. E. (2000). Evidence for longterm cervical persistence of Chlamydia trachomatis by omp1 genotyping. J Infect Dis 182, 909-916. 
Eckert, L. O., Suchland, R. J., Hawes, S. E. \& Stamm, W. E. (2000). Quantitative Chlamydia trachomatis cultures: correlation of chlamydial inclusion-forming units with serovar, age, sex, and race. J Infect Dis 182, 540-544.

Eley, A. \& Khalili, M. (1993). Mixed infections of Chlamydia trachomatis may be missed using nested PCR. Genitourin Med 69, 481.

Frost, E. H., Deslandes, S., Gendron, D., Bourgaux-Ramoisy, D. \& Bourgaux, P. (1995). Variation outside variable segments of the major outer membrane protein distinguishes trachoma from urogenital isolates of the same serovar of Chlamydia trachomatis. Genitourin Med 71, 18-23.

Gaydos, C. A., Theodore, M., Dalesio, N., Wood, B. J. \& Quinn, T. C. (2004). Comparison of three nucleic acid amplification tests for detection of Chlamydia trachomatis in urine specimens. J Clin Microbiol 42, 3041-3045.

Grayston, J. T. \& Wang, S. (1975). New knowledge of chlamydiae and the diseases they cause. J Infect Dis 132, 87-105.

Hsieh, C. Y., You, S. L., Kao, C. L. \& Chen, C. J. (1999). Reproductive and infectious risk factors for invasive cervical cancer in Taiwan. Anticancer Res 19, 4495-4500.

Ikehata, M., Numazaki, K. \& Chiba, S. (2000). Analysis of Chlamydia trachomatis serovars in endocervical specimens derived from pregnant Japanese women. FEMS Immunol Med Microbiol 27, 35-41.

Jonsdottir, K., Kristjansson, M., Hjaltalin, O. J. \& Steingrimsson, O. (2003). The molecular epidemiology of genital Chlamydia trachomatis in the greater Reykjavik area, Iceland. Sex Transm Dis 30, 249-256.

Jurstrand, M., Falk, L., Fredlund, H., Lindberg, M., Olcen, P., Andersson, S., Persson, K., Albert, J. \& Backman, A. (2001). Characterization of Chlamydia trachomatis omp1 genotypes among sexually transmitted disease patients in Sweden. J Clin Microbiol 39, 3915-3919.

Koskela, P., Anttila, T., Bjorge, T. \& 13 other authors (2000). Chlamydia trachomatis infection as a risk factor for invasive cervical cancer. Int J Cancer 85, 35-39.

Lee, G., Park, J., Kim, B., Kim, S. A., Yoo, C. K. \& Seong, W. K. (2006). ompA genotyping of Chlamydia trachomatis from Korean female sex workers. J Infect (in press).

Lister, N. A., Tabrizi, S. N., Fairley, C. K. \& Garland, S. (2004a). Validation of Roche COBAS Amplicor assay for detection of Chlamydia trachomatis in rectal and pharyngeal specimens by an omp1 PCR assay. J Clin Microbiol 42, 239-241.

Lister, N. A., Tabrizi, S. N., Fairley, C. K., Smith, A., Janssen, P. H. \& Garland, S. (2004b). Variability of the Chlamydia trachomatis omp1 gene detected in samples from men tested in male-only saunas in Melbourne, Australia. J Clin Microbiol 42, 2596-2601.

Lysén, M., Osterlund, A., Rubin, C. J., Persson, T., Persson, I. \& Herrmann, B. (2004). Characterization of ompA genotypes by sequence analysis of DNA from all detected cases of Chlamydia trachomatis infections during 1 year of contact tracing in a Swedish county. J Clin Microbiol 42, 1641-1647.

Mahony, J. B., Luinstra, K. E., Sellors, J. W. \& Chernesky, M. A. (1993). Comparison of plasmid- and chromosome-based polymerase chain reaction assays for detecting Chlamydia trachomatis nucleic acids. J Clin Microbiol 31, 1753-1758.

Marrazzo, J. M. \& Stamm, W. E. (1998). New approaches to the diagnosis, treatment, and prevention of chlamydial infection. Curr Clin Top Infect Dis 18, 37-59.

Molano, M., Meijer, C. J., Morre, S. A., Pol, R. \& van den Brule, A. J. (2004). Combination of PCR targeting the VD2 of omp1 and reverse line blot analysis for typing of urogenital Chlamydia trachomatis serovars in cervical scrape specimens. J Clin Microbiol 42, 2935-2939.
Morre, S. A., Ossewaarde, J. M., Lan, J., van Doornum, G. J., Walboomers, J. M., MacLaren, D. M., Meijer, C. J. \& van den Brule, A. J. (1998). Serotyping and genotyping of genital Chlamydia trachomatis isolates reveal variants of serovars $\mathrm{Ba}, \mathrm{G}$, and $\mathrm{J}$ as confirmed by omp1 nucleotide sequence analysis. J Clin Microbiol 36, 345-351.

Morre, S. A., Rozendaal, L., van Valkengoed, I. G. \& 8 other authors (2000). Urogenital Chlamydia trachomatis serovars in men and women with a symptomatic or asymptomatic infection: an association with clinical manifestations? J Clin Microbiol 38, 2292-2296.

Ngandjio, A., Clerc, M., Fonkoua, M. C. \& 7 other authors (2003). Screening of volunteer students in Yaounde (Cameroon, Central Africa) for Chlamydia trachomatis infection and genotyping of isolated C. trachomatis strains. J Clin Microbiol 41, 4404-4407.

Ngandjio, A., Clerc, M., Fonkoua, M. C., Thonnon, J., Lunel, F., Bebear, C., Bianchi, A. \& De Barbeyrac, B. (2004). Restriction endonuclease patterns of the omp1 gene of reference Chlamydia trachomatis strains and characterization of isolates from Cameroonian students. J Med Microbiol 53, 47-50.

Parish, W. L., Laumann, E. O., Cohen, M. S., Pan, S., Zheng, H., Hoffman, l., Wang, T. \& Ng, K. H. (2003). Population-based study of chlamydial infection in China: a hidden epidemic. JAMA 289, 1265-1273.

Pedersen, L. N., Kjaer, H. O., Moller, J. K., Orntoft, T. F. \& Ostergaard, L. (2000). High-resolution genotyping of Chlamydia trachomatis from recurrent urogenital infections. J Clin Microbiol 38, 3068-3071.

Peterson, E. M., You, J. Z., Motin, V. \& de la Maza, L. M. (1999). Intranasal immunization with Chlamydia trachomatis, serovar $\mathrm{E}$, protects from a subsequent vaginal challenge with the homologous serovar. Vaccine 17, 2901-2907.

Schachter, J., McCormack, W. M., Chernesky, M. A. \& 7 other authors (2003). Vaginal swabs are appropriate specimens for diagnosis of genital tract infection with Chlamydia trachomatis. J Clin Microbiol 41, 3784-3789.

Singh, V., Salhan, S., Das, B. C. \& Mittal, A. (2003). Predominance of Chlamydia trachomatis serovars associated with urogenital infections in females in New Delhi, India. J Clin Microbiol 41, 2700-2702.

Spaargaren, J., Fennema, H. S., Morre, S. A., de Vries, H. J. \& Coutinho, R. A. (2005). New lymphogranuloma venereum Chlamydia trachomatis variant, Amsterdam. Emerg Infect Dis 11, 1090-1092.

Stephens, R. S., Sanchez-Pescador, R., Wagar, E. A., Inouye, C. \& Urdea, M. S. (1987). Diversity of Chlamydia trachomatis major outer membrane protein genes. J Bacteriol 169, 3879-3885.

Stothard, D. R., Boguslawski, G. \& Jones, R. B. (1998). Phylogenetic analysis of the Chlamydia trachomatis major outer membrane protein and examination of potential pathogenic determinants. Infect Immun 66, 3618-3625.

Sturm-Ramirez, K., Brumblay, H., Diop, K. \& 7 other authors (2000). Molecular epidemiology of genital Chlamydia trachomatis infection in high-risk women in Senegal, West Africa. J Clin Microbiol 38, 138-145.

Suchland, R. J. \& Stamm, W. E. (1991). Simplified microtiter cell culture method for rapid immunotyping of Chlamydia trachomatis. J Clin Microbiol 29, 1333-1338.

Vincelette, J., Schirm, J., Bogard, M., Bourgault, A. M., Luijt, D. S., Bianchi, A., Voorst Vader, P. C., Butcher, A. \& Rosenstraus, M. (1999). Multicenter evaluation of the fully automated COBAS AMPLICOR PCR test for detection of Chlamydia trachomatis in urogenital specimens. J Clin Microbiol 37, 74-80.

Wang, S. P., Kuo, C. C., Barnes, R. C., Stephens, R. S. \& Grayston, J. T. (1985). Immunotyping of Chlamydia trachomatis with monoclonal antibodies. J Infect Dis 152, 791-800. 
Wiesenfeld, H. C., Heine, R. P., Rideout, A., Macio, I., DiBiasi, F. \& Sweet, R. L. (1996). The vaginal introitus: a novel site for Chlamydia trachomatis testing in women. Am J Obstet Gynecol 174, 1542-1546.

Woegerbauer, M., Jenni, B., Thalhammer, F., Graninger, W. \& Burgmann, H. (2002). Natural genetic transformation of clinical isolates of Escherichia coli in urine and water. Appl Environ Microbiol 68, 440-443.

Wu, C. H., Lee, M. F., Yin, S. C., Yang, D. M. \& Cheng, S. F. (1992). Comparison of polymerase chain reaction, monoclonal antibody based enzyme immunoassay, and cell culture for detection of
Chlamydia trachomatis in genital specimens. Sex Transm Dis 19, 193-197.

Yamazaki, T., Hagiwara, T., Kishimoto, T., Sasaki, N., Takahashi, S., Ishihara, O., Wangroongsarb, P., Kusum, M. \& Sirivongrangsan, P. (2005). Distribution of Chlamydia trachomatis serovars among female prostitutes and non-prostitutes in Thailand, and nonprostitutes in Japan during the mid-90s. Jpn J Infect Dis 58, 211-213.

Yuan, Y., Zhang, Y. X., Watkins, N. G. \& Caldwell, H. D. (1989). Nucleotide and deduced amino acid sequences for the four variable domains of the major outer membrane proteins of the 15 Chlamydia trachomatis serovars. Infect Immun 57, 1040-1049. 